Vol. $7, n^{\circ} 2 \mid 2003$

Varia

\title{
Resistance and repression in India: the hunger strike at the Andaman cellular jail in 1933
}

Pramod Kumar Srivastava

\section{(2) OpenEdition}

Electronic version

URL: https://journals.openedition.org/chs/548

DOI: $10.4000 /$ chs. 548

ISSN: 1663-4837

Publisher

Librairie Droz

Printed version

Date of publication: 1 December 2003

Number of pages: 81-102

ISBN: 2-600-008990-3

ISSN: 1422-0857

\section{Electronic reference}

Pramod Kumar Srivastava, "Resistance and repression in India: the hunger strike at the Andaman cellular jail in 1933", Crime, Histoire \& Sociétés / Crime, History \& Societies [Online], Vol. 7, n² | 2003, Online since 25 February 2009, connection on 23 March 2022. URL: http://journals.openedition.org/ chs/548 ; DOl: https://doi.org/10.4000/chs.548

This text was automatically generated on 23 March 2022.

(c) Droz 


\title{
Resistance and repression in India: the hunger strike at the Andaman cellular jail in 1933
}

\author{
Pramod Kumar Srivastava
}

I know destruction awaits him,

Who first rises

Against the oppressors yoke; My fate is sealed and closed, But tell me where and when

Without victims

Was ever freedom won?

For my native land I perish

I feel it and I know it

And in my heart 0 Holy father

My far star I bliss! [Pushkin] ${ }^{1}$

1 Hunger strikes had become popular with both the political streams of the nationalist movement of India -Gandhi's non-violent platform and the militant nationalists terrorist movement. There were several instances of hunger strikes by political prisoners, convicts and detenus in the mainland prisons and in the penal settlement at the Andaman Islands. Some of the Lahore Conspiracy Case prisoners at Hazaribagh Jail in 1918 resorted to a hunger strike to protest against the nature of their incarceration. At about the same time there were hunger strikes in Bengal and Bihar among detenus ${ }^{2}$. The militants nationalists of the Hindustan Socialist Republican Association (HSRA) arrested in the $2^{\text {nd }}$ Lahore Conspiracy Case, used hunger strike as a political weapon to protest that their grievances in the prisons were not being redressed. Yatindra Nath Das, a member of HSRA, had died on $13^{\text {th }}$ September 1929 in Lahore prison after 63 days of hunger strike ${ }^{3}$. Mahatma Gandhi, used the fast, as a non-violent weapon, to teach moral principles to his followers ${ }^{4}$. Later, he also used it as an effective non-violent weapon to enforce his own followers in particular and the people of India in general. Whereas Gandhi's fasts were an individual act of a spiritual kind, the hunger strikes 
were mostly collective and united efforts to challenge jail authorities and the colonial government. However, none of these compared in significance with the forty-five day old hunger strike of 1933 at Andaman Islands. By paying the price of three lives this hunger strike kept the spirit of anti-colonial struggle alive in the lull after the failure of Gandhi's Civil Disobedience Movement of 1930. It also exposed the nature of colonial disciplining of political prisoners, the negligence of jail authorities during the forced feeding of the hunger strikers, and the essence of the transportation policy of the Government of India. The colonial bureaucracy was determinated that the use of hunger strike as a technique of insubordination should be discouraged by not granting any concessions, yet it was forced to accept a humiliating compromise.

The hunger strikes by the political prisoners in twentieth century were an extension of the outburst of the militant resistance movement against the British colonialism. It is not a coincidence that the idea of hunger strike originated in the cellular jail only after the first generation of militant nationalists were transported to Andaman Islands. Though the nature of penal settlement remained almost same throughout nineteenth century the meaningful protest was not witnessed before 1912. The idea of hunger strike was nevertheless rooted in the inherent contradictions between the theory and practice of colonial bureaucracy in disciplining ordinary convicts and political prisoners. Singh noted, «unlike transported convicts who were kept in the cellular jail for short terms, political prisoners at Andamans, in the early decades of the $20^{\text {th }}$ century, suffered the dual punishment of transportation and harsh imprisonment in the cellular jail for the entire term of their sentence» ${ }^{5}$.

\section{The penal settlement: Colonialism, Rebellion and Repression}

3 The idea of penal settlement originated in India with the beginning of colonialism, and was abolished only after India achieved freedom from British rule. In view of Macaulay, the drafter of Indian Penal Code and a pioneer of the colonial prison system, transportation was significant «as a punishment for Indian criminals» ${ }^{6}$. It was viewed as more painful and deterrent for Indians than for English criminals. The foremost objective in transportation during the eighteenth century was the requirement of labour for the exploitation of the natural resources of the islands where such penal settlements were established. Hence convicts above 18 and below 40 years of age, and medically fit for hard labour were chosen for such settlements. Sen has noted that in 1818, Stamford Raffles, the Governor of Sumatra, had indicated to the Government of India, that the employment of prisoners in various forms of labour might enable a selfsustaining colony ${ }^{7}$. However, since 1858 penal settlement for Indian convicts was limited to the Andaman Islands alone.The rules and regulations framed in 1827 for Benkoolen or Penang were applied here as well.

4 The revolt of 1857 in India created a problem about accomodating the large number of mutineers in the mainland jails. This was the direct and immediate context in which a penal settlement was established at Port Blair. Thereafter, a large number of the Wahabi rebels were transported. Yet by 1889 , a Committee sent by Government of India, held, «the punishment of transportation was not deterrent»; and prophesied, «before long this form of punishment would cease to exist». They said that transportation, "was decidedly retributive and as such opposed to the fundamental principles of modern 
penology» ${ }^{8}$. Nevertheless transportation to Andamans continued and in fact, the Government of India began constructing a cellular jail in 1896, which was completed in 1910. It was a well built and scientifically planned three storeyed fine building standing on a bold promontory close to the sea, about 100 feet above the sea level ${ }^{9}$. It had seven wings with 690 cells connected from a central tower. The central tower had an additional storey to provide room for watch guards ${ }^{10}$.

5 The rapid growth of the militant nationalist movement against British colonialism during early years of the twentieth century added one more factor to the existing objective of penal settlement. It was a new situation in which the colonial authorities «seemed apprehensive of confining the nationalists on the mainland where they could spread their 'dangerous' ideas»" ${ }^{11}$. Thereafter, the deportation of political prisoners to the penal settlement at Andaman Islands increased manifold. The division on the basis of political and non-political prisoners at Andamans was made in 1909 when Sir J. P. Hewett the governor of United Provinces requested the transportation of Hoti Lal Verma and Ram Hari, the editors of the Urdu weekly «Swarajya», published from Allahabad, who were convicted and sentenced to seven years of transportation. In 1906 the Government had suspended the deportation of term convicts, so his request was turned down. The government reopened the transportation of political prisoners sentenced for various terms after the judgement of the Alipore Bomb case, which pronounced that there was a conspiracy to overthrow the British government in India $^{12}$. In 1910, the convicts of the Khulna conspiracy case and the Alipore conspiracy case were transported, so too was Damodar Vinayak Savarkar, for the first and second Nasik conspiracy case. He would later write Story of Transportation for Life about this sentence.

6 The arrival of so many political prisoners in cellular jail provided an opportunity for them to unite against the disciplinary regime of the colonial prison administration. This resulted into a series of hunger strikes, work stoppages, and rumours of bomb manufacture by political prisoners in 1912. All such disturbances at the settlement were, in fact, an expansion of the anti-colonial resistance movement in the mainland. The propaganda impact of this minor resistance movement became a point of concern for the colonial government. The publication of prisoner's letters in the vernacular press, mass demonstration at the mainland about the treatment of political prisoners in the cellular jail, and the embarrassing questions in the Imperial Legislative Assembly forced the Government of India to send Sir Reginald Craddock to make an inquiry to prove that political prisoners were not unduly tormented in the Andamans ${ }^{13}$. Craddock's findings were described as «neither impartial nor particularly rigorous». The colonial jail administration of cellular jail was completely exonerated. Yet Satadru Sen says the inquiry gave an impression of «transparency» and "official concern», and "these were central to the politics of surveillance in the colonial context» ${ }^{14}$. During the First World War 77 convicts of the First Lahore Conspiracy case, connected with the well-known Ghadr movement, were transported. There were 133 political prisoners in Andamans between 1910 to $1920^{15}$. 


\section{Transportation policy: The segregation of dangerous ideas}

7 In theory the penal settlement was abandoned in 1921 after the transportation policy of the Government of India was announced by Sir William Vincent in the Legislative Assembly on $11^{\text {th }}$ March 1921. Sir Vincent said that the government of India had decided to abandon the penal settlement but abandonment had to be gradual, as it involved 12,000 to 15,000 prisoners. He also mentioned that orders have already been issued for the immediate return of «all political prisoners and female prisoners not married locally.» The local governments were directed not to send more criminals to Andamans. However, in November 1921 owing to the overcrowding of jails in India, and a consequent deterioration in administration and discipline and grave danger of large scale epidemics, it was found necessary to re-open transportation to the Andamans. Even so, the Government of India emphasised that the transportation of females, political offenders and prisoners suspected of a tendency to unnatural vice would be absolutely prohibited ${ }^{16}$.

In pursuance of this policy, the convicts who had «suffered in health» or had proven «incorrigible in conduct» were transferred to the jails in India. Transfers from India were severely curtailed and almost completely stopped. The remaining convicts were given various inducements to stay on as free settlers, viz. relaxation of conditions, grant of «ticket of leave» after a short period of probation and facilities for getting the convicts' wives from India ${ }^{17}$. In 1921, when Government decided to close the settlement the convict population numbered 11,532; by December, 1926, their number declined to $7,740^{18}$. This reduction resulted in a shortage of labour so that the local authorities initiated a process of obtaining volunteer convicts from Indian jails ${ }^{19}$.

9 In 1932 the Government of Bengal proposed to transfer about 100 Terrorist (Militant Nationalist) convicts, including three women, to the Andamans from the jails of Bengal. The Government of Bengal regarded the proposal as an essential both to maintaining discipline in jails and deterring terrorism. It argued «that other Indian provinces were unwilling to take detenus and there was, therefore no alternative to the Andamans» ${ }^{20}$. The Government of India supporting the proposal, said the prisoners to be transferred would be «composed of persons serving sentences of transportation for terrorist outrages and sentences of rigorous imprisonment for similar offences». The 3 women convicts proposed to be transported to Andamans were those concerned in the shooting of Mr. Stevens and in the attempt on Sir Stanley Jackson. The «transportation» prisoners would be placed in the cellular jail and the others would serve out their sentences in ordinary jail, just as in an Indian jail. «They will all be kept entirely separate, from the other prisoners in the Andamans and out of contact with the settlement. The 3 women will be kept entirely separate with no danger of association with other convicts» ${ }^{21}$.

Since the proposals of transportation were against the declared policy of the colonial government it was found essential to justify it. It was not surprising, therefore, that Sir Charles Tegart, the Legal Adviser to the Secretary of State, found no legal objections. «Prisoners may be removed to any Indian prison» Tegart rationalised, «by an order passed under section 29 of the Prisoners Act and the Andamans is a part of British India». So far the declared policy of the Government of India, in regard to the total abandonment of the penal settlement was concerned, he argued, «it will not be the first 
time that transportation to the Andamans has been re-opened since the announcement of $1921 »^{22}$. According to Tegart there was no legal objection to the transportation of prisoners who were sentenced to rigorous imprisonment because they would be treated in all respects as though they were serving their sentences in an inland prison. There remained the fact that the Secretary of State and the Government of India had always, since 1921, agreed that the transportation of women and political prisoners to the Andamans would be prohibited in future. Regarding the transportation of political prisoners the Secretary of State argued: «The Government of India, however, point out that for many years they have refused to recognise the term 'political prisoners' which finds no place in the new Classification of Rules. Moreover, they are strongly of opinion that no consideration should be shown to persons convicted of offences connected with murderous conspiracies merely because a political motive is involved $»^{23}$. Regarding the transportation of the women convicts, the Government of India said, «unless measures are adopted which will be regarded as a deterrent against women terrorists, there was a serious danger that women will continue, and will be encouraged, to commit such crimes». The Government of India stated that adequate measures would be taken for the maintenance, health and guarding of the prisoners, and suggested that it would probably be convenient to treat them all as «B» class prisoners. The cost of maintenance was to be borne by the Government of Bengal. The proposal of the Government of India was accepted in Britain, the Secretary of State stating that he had received it with regret but recognised the necessity for sanctioning the measures. However, only those prisoners were to be transported from Bengal who were convicted of offences in connection with terrorist crimes ${ }^{24}$.

11 The first batch of 25 prisoners from Bengal was sent on $15^{\text {th }}$ August $1932^{25}$. The decision to despatch a first batch of prisoners was taken in extraordinary haste ${ }^{26}$. Up till May 1933, four batches of political prisoners were sent to Port Blair from Bengal and other parts of India via Alipore Central jail ${ }^{27}$. There were 100 political prisoners in cellular jail in March $1933^{28}$. The Government of India also confirmed that 100 political prisoners from Bengal were transported up to $25^{\text {th }}$ May $1933^{29}$. Since they were transported for their nationalist ideas and not for the purpose of labour it is not surprising that the age factor was not taken into account. At least six prisoners - Anand Prasad Gupta, Sahairam Das, Fakir Chandra Sen, Haripada Bhattacharjee, Sudhendu Bikash Dastidar and Hira Mohan Chatterjee - when transported to the Andamans were youths below 18 years of age ${ }^{30}$.

12 However, the Government of India did not rest content with removing political prisoners from Bengal alone. On the basis of the three Reports received from the Government of Bihar and Orissa in $1930^{31}, 1931^{32}$ and $1932^{33}$, the Government of India asked on $3^{\text {rd }}$ November 1932 for approval of the transfer of five terrorist convicts from Bihar and to the Andamans cellular jail and for discretion to transfer terrorist convicts from any province to the Andamans. The Government of India said that the transfer of convicts to the Andamans jail had the great advantage of deterrence, of preventing escape and of preventing communication with accomplices outside the prison walls. It also contended that since they were proposing to send only long term convicts to the Andamans, the risk of further contamination in the cellular jail was most certainly outweighed by the risks involved in keeping them in jail in their homeland. It was also argued that there was plenty of room in the Andamans cellular jail, with its 700 cells 
and a normal population of not more than 300. It declared that it was impossible now to suggest that the Andamans were an «unhealthy» place for convicts ${ }^{34}$.

The office of the Secretary of State was well aware that there was actually no serious outbreak of militancy in Bihar between 1930 and $1932^{35}$ yet it not only approved the transfer of 5 Bihari convicts to Andamans, but also agreed to vest the Government of India with discretion in regard to further transfers of terrorist convicts from Bihar or other provinces ${ }^{36}$. Thereafter in the period up to 25 May 1933, six political convicts from Bihar and Orissa and eight from Punjab and Delhi were transported.

The total number of political prisoners transported to Andaman on the eve of hunger strike was $117^{37}$.

The total number of political prisoners at the time of hunger strike was $112^{38}$.

The Government of India had given the undertaking, «that adequate measures for the maintenance, health and guarding of the prisoners will be taken and that it will probably be found most convenient to treat them all as «B» class prisoners» ${ }^{39}$. Yet in disregard of this, many of the transferred political prisoners were not only treated as «C» class prisoners but were subjected to hard labour and severe punishments for indiscipline. One example of hard labour was the grinding of 30 pounds of oil everyday from an Oil Mill to which the convict was tied down in place of bullocks. Choir pounding was another common labour task. Apart from solitary confinement, another typical punishment included a standing position for several hours with both hands handcuffed. The newspaper Jnanananda reported «The Division III prisoners were given very bad diet, simply unsuitable for human consumption. They were not supplied with any light at night in their cells. No money was accepted at the jail gate as personal cash in the name of any class of prisoners, in some cases money orders from relatives were even refused and money was withheld, if they were any. They were not allowed to get their food cooked in a joint kitchen with Division II prisoners $»^{40}$.

\section{Hunger strike: A Weapon of Political Resistance}

17 The arrival of the militant nationalist prisoners from Bengal encouraged the prisoners to present a united resistance to the jail administration. On January $3^{\text {rd }}, 1933$ seven of the political prisoners-Bimal Kumar Das Gupta, Sushil Kumar Das Gupta, Probodh Chandra Roy, Prabir Goswami, Bimlendu Chakravorty, Barindra Kumar Ghosh ${ }^{41}$, and Subodh Roy- went on hunger strike. This was the second hunger strike in the cellular jail. The prisoners outlined 15 demands including, «Better rice and vegetables for $\mathrm{C}$ class; Special dietary for vegetarians; Flat-faced pots for night urinals in place of lotas; Emola soap for all prisoners; Better hospital arrangements; Latrine arrangements to be improved. Each compartment to be screaned off; Bed-sheets and towels for $\mathrm{C}$ class as well as for B class ${ }^{{ }^{42}}$. The strike lasted from January $3^{\text {rd }}$ to January $9^{\text {th }} 1933$. The condition of the hunger strikers remained stable so forced feeding was not required but disciplinary action was taken against them on the orders of the Chief Commissioner ${ }^{43}$.

The historic third hunger strike commenced four months after the failure of the second hunger strike. Barindra Kumar Ghosh, a participant in the both hunger strikes of 1933, recalled: «We decided to commence next strike after arrival of another batch. After the arrival of B.K. Dutta and Bhupal Ghosh we gave an ultimatum of one month to redress their grievances. But the government said that nothing could be done. Thereafter one- 
month time was given to each of us to think who shall take part in the hunger strike because after beginning it once it was not to be broken. Fifty-six prisoners were in division three. Twenty-three of them participated in the hunger strike. Rest of them decided not to work. It began on $12^{\text {th }}$ May $1933 »^{44}$.

There was no unanimity among all the political prisoners over the issue of beginning a hunger strike in cellular jail. Dhirendra Nath Choudhury, a participant in the hunger strike recalled that there were only 15-16 political prisoners before the arrival of his batch of thirty-five prisoners. When they decided to begin a hunger strike all those present before the arrival of his batch refused to participate. They said they were few in number, and that as convicts for life they would have to stay on while the instigators of the hunger strike, the term prisoners, would leave after some time. Therefore, it was decided to wait for the arrival of other comrades. Till then they kept on working and quarrelling with officers. Thereafter, another group of six prisoners arrived, whose names Mr. Choudhury did not want to reveal. They too refused to participate saying they were not familiar with the conditions prevailing in the cellular jail. In addition there was no communication with the mainland so, no one would set to know about the hunger strike. Subsequently Shiv Verma, Batukeshwar Dutta and others of second Lahore conspiracy case arrived from Punjab but they too refused. Here there is a discrepancy between the version of Mr Choudhury and Bejoy Kumar Sinha. According to Sinha, Shiv Verma and Jaideo Kapoor arrived on $14^{\text {th }}$ June ${ }^{45}$. Therefore, there was no question of refusal from them. Shiv Verma and Jaideo Kapoor give the same date for their transportation. However, the records of the Chief Commissioner of Andaman Islands put Shiv Verma, Jaideo Kapoor and Bejoy Kumar Sinha as present in the Cellular Jail on $25^{\text {th }}$ May $1933^{46}$. The instigators did have to wait for some more time till a group arrived from Bengal who were ready for the struggle. Finally, an ultimatum was given to jail administration before beginning the hunger strike ${ }^{47}$. The new arrivals were unaware of the prisoner's grievances in the cellular jail yet prompted by nationalist ideas they united with their comrades in the hunger strike.

The condition of political prisoners in the cellular jail had not improved since the first hunger strike and Craddock' s visit in 1912-1913. Yet no such resistance had taken shape in the cellular jail over the last two decades. The hope of constitutional remedies generated during First World War, the non-violent movement of 1919-1922 under the leadership of Gandhi and abandonment of transportation of political prisoners after 1921 had introduced certain inconsistencies in the resistance movement. Yet the mode of disciplining political prisoners in the settlement remained draconian. Achyut Ghatak, a participant in the hunger strike, recalled: «When we arrived Andamans no one of us could think of returning back alive. It was a jungle. No sooner we were in the jail compound it appeared as if we were in a hell. I went in the third batch. Those who had arrived in the first and the second batch had made enough preparations. They were waiting for the arrival of the third batch to commence their joint struggle against the jail Superintendent. There was no arrangement of electricity. Mosquitoes were plenty but mosquito net was not provided. Food was deplorable. In those conditions we all decided that it was preferable to die sooner by observing hunger strike than to die slowly $»^{48}$. Vidhu Bhusan Sen, another participant in the hunger strikes mentioned: «There were big scorpions in the cells. Its biting resulted into high fever. In the morning we were provided Lapsi (an item made up of boiled rice and water) without salt. Food was worst. I was class 3 prisoner» ${ }^{49}$. Dhirendra Nath Choudhury, a convict of Maniktala Dacoity Case, narrated: «Cells were in deplorable condition... A number of 
scorpions were in the cells. In each cell one convict was incarcerated. The cells were 10 feet long and 6 feet broad. In each cell there was an iron door and a small window. The cells were so dark that one could see only after shutting his eyes for a while. We were provided very dirty food to eat...We were given the work of coir pounding ${ }^{50}$. On the issue of demanding better conditions in the cellular jail, militant nationalists in fact commenced a new struggle in jail. The demands of hunger strikers included light in their cell till 10 p.m., weekly and monthly newspapers, right of petitioning both central and local Governments, an extensive and varied diet including a choice of vegetables and tooth powder, tooth paste and sandals, etc ${ }^{51}$.

21 After the ultimatum was lapsed the political prisoners began their hunger strike in the cellular jail on $12^{\text {th }}$ May $1933^{52}$. The jail authorities held that B. K. Dutta and Kamal Nath, were the prime movers behind the strike and they segregated them from the rest of the hunger strikers who were in yard No. $5^{53}$. The other leaders of the hunger strike were those who had participated in the hunger strike of January $3^{\text {rd }}, 1933$.

The objective of the hunger strike was not limited to protest against the deplorable conditions to which ' $C$ ' class convicts were subjected in the cellular jail. It was a part of the nationalist resistance movement going on the mainland since beginning of the twentieth century. It is not surprising therefore that the hunger strike did not remain confined to the ' $C$ ' class prisoners. Soon six «B» class convicts also joined. However, the demands of ' $C$ ' class and ' $B$ ' class hunger strikers were not identical. The «B» class convicts were demanding a supply of newspapers from many countries at Government's expense, permission to receive money and the right to petition Central and Local Governments ${ }^{54}$. Yet, the cellular jail administration put about the idea that compliance with the demands of the ' $C$ ' class prisoners would place them in the same position as 'B' class convicts 5 .

In fact, nowhere in Indian Jails were ordinary ' $C$ ' class convicts kept in such deplorable conditions. The provisions of the jail code were grossly neglected by the cellular jail administration. Article 466 of the Jail Code maintained: «A kerosene Hurricane lamp or other light suspended from an iron rod, eight or nine feet from the ground shall be kept burning in every sleeping ward». The next provision said: «It is the duty of the patrolling officer and of both the warders and convict watchmen to see that all the night lamps are kept burning brightly» ${ }^{56}$. Their demand of "an extensive and varied diet including a choice of vegetables», was not contrary to the article 1052 of the Jail Code regarding the sanction of diet for the ' $\mathrm{C}$ ' class convicts. The article sanctioned Rice and Salt (well-known in jails as 'Lapshi') for early morning meal and Rice, Dal and Vegetables for other meals. In addition it provided, «in all jails, ration of fish at the rate of _ chattack per head shall be given on alternate day at one or other of the daily meals...Meat can be substituted for fish provided the cost remains the same» ${ }^{57}$. As against it the diet supplied to the ' $C$ ' class convicts was simply unsuitable for human consumption. They were forced to consume rice «mixed with varieties of grains and small stones». In the name of vegetables they were given practically leaves and grasses. Neither fish nor meat in lieu of fish was ever supplied to them.

The ' $\mathrm{B}$ ' class prisoners were not supplied with any weekly newspapers or magazines as approved by the Jail Code: «Periodical news may be published in English or in Bengali in the form of a Jail Newspaper at the expense of the Government and supplied to the literate prisoners in both divisions I and II. If no Jail newspaper is published or if it is not possible to undertake its production prisoners in division I and II shall be supplied 
with a few copies of a weekly newspaper from a list of newspapers to be approved by the Government $\aleph^{58}$. In the jails of mainland Bengal ' $\mathrm{B}$ ' class prisoners were supplied with the «Englishman», «Statesman» and «Sanjibani». They could also subscribe to these papers at their own expense ${ }^{59}$.

The Cellular Jail administration accepted no money at the jail gate as personal cash in the name of any class of prisoners. In some cases money orders from relatives were refused or withheld from them. Yet, the Jail Code clearly established the prisoner's right to have money as personal cash in custody ${ }^{60}$. The prisoners, at their own cost or that of their friends, were allowed to have fruits and uncooked food including milk on festivals at the discretion of the superintendent ${ }^{61}$. They were allowed to observe DurgaPuja, SaraswatiPuja, DoleJatra, Idul-Fitr, Iduzzoha, Mohurrum, Christmas, Good Friday and King Emperors' Birthday ${ }^{62}$. The Jail Code even allowed prisoners to see a visitor once a fortnight in the case of a Division I prisoner or once a month in the case of Division II prisoner ${ }^{63}$. However, the Andaman prisoners were allowed to see a visitor only once in six months.

\section{The forced feeding: The Repression and the Safe Custody}

On $17^{\text {th }}$ May 1933 the hunger strikers began to be force fed. The legality of forced feeding was established with an amendment in the Bengal Jail Code, 1910, whereby a prisoner could be fed «in such manner as the circumstances appear to the medical officer to warrant $\rangle^{64}$. There was also a direction of the Government of India, dated the $23^{\text {rd }}$ October 1922, addressed to all Local Governments and Administrations regarding «Forcible feeding of hunger strikers» ${ }^{65}$. It mentioned a judgment of the Lord Chief Justice in the case of Leigh vs. Gladstone, related to an action claiming damages for assault and for an injunction, brought by a suffragette against the Home Secretary, the Governor of the Prison and the Medical Officer of the Prison. The Lord Chief Justice observed, «It was the duty, both under the rules and apart from the rules, of the officials to preserve the health and lives of the prisoners, who were in the custody of the Crown. If they forcibly fed the plaintiff when it was not necessary, the defendants ought to pay damages $»^{66}$. In the light of this judgment the Government of India made it clear that the jail superintendents could employ forced feeding on the argument of «safe custody» ${ }^{67}$.

The procedure of the forced feeding was a scientifically devised method recommended by a Committee of medical officers, which met at Lahore in 1929 to advise on the treatment of hunger strikers in the Lahore Conspiracy Case. It was a tortuous procedure employed in the garb of a policy of «safe custody» of prisoners. The prisoner on hunger strike was forced to lie down on a low bed, with his head slightly raised on a pillow. Thereafter, three or four attendants would hold his head and limbs, while the doctor inserted a rubber "catheter» through the nostril into the gullet and so to the stomach. The nourishment included milk with sugar and raw eggs; and the amount given was 10 oz to $1 \frac{1 / 2}{2} \mathrm{l}^{68}$. Since hunger strikers were determined to resist forced feeding each procedure took several hours, which resulted into a struggle between hunger striker and the attendants. According to Achyut Ghatak, a participant in the hunger strike, hunger strikers devised a remarkable way of resisting forced feeding. During nasal insertion of the catheter tube they would cough heavily to shift the tube's end from 
glut to mouth and hold it tightly between their teeth to foil forced feeding ${ }^{69}$. It was not unlikely that use of physical strength by either party could cause the catheter tube to pass into the lungs instead of the stomach and cause severe pneumonia and even a painful death. The colonial fear of «dangerous ideas» was so intense that such a tortuous procedure not only found the sanction of the legal system but the element of dehumanisation involved in the operation was overlooked.

The death of three hunger strikers after forced feeding confirmed the duplicity of the policy of «safe custody» upon which forced feeding was sanctioned. Mahabir Singh, a Lahore Conspiracy convict, who arrived at Andamans from Madras jail in January 1933, died at 12.24 a.m. on $18^{\text {th }}$ morning, within twenty-four hours of forced feeding. Yet the jail authorities denied any carelessness in the procedure. In his telegram to the Government of India the Chief Commissioner of Andaman Islands stated: «Post mortem examination shows that death was due to shock and not to any carelessness in the administration of food. Three other convicts show sign of serious weakness, but condition of remainder is quite satisfactory ${ }^{70}$.

29 Up to the $16^{\text {th }}$ Mahabir Singh's condition was satisfactory, though he was weak. The Senior Medical Officer saw him on the $17^{\text {th }}$ morning and artificial feeding was considered necessary. At 11 a.m. 24 ounces of milk and one of sugar were given by nasal feeding. Mahabir Singh resisted very violently both while the tube was being inserted and while the milk was being poured down. His condition became bad - pulse quick, respiration difficult and hurried, and cold sweat on the forehead - at I p.m. his body was somewhat cold and displayed evident signs of shock. At 4 p.m. he complained of tightness of the chest and difficulty of breathing. The Senior Medical officer saw him and prescribed treatment. He saw him again at 7.30 p.m. and noticed signs of collapse. He sank gradually and death occurred at 12.24 a.m. ${ }^{11}$.

30 According to the Chief Commissioner the post mortem examination showed no sign either of «external or internal injury» to his body as a result of actual operation of feeding. His resistance, which was more violent than that offered by any other convict, in his weakened state caused a severe shock to his system and led to his collapse. «I am quite satisfied» said the Chief Commissioner, «that all due precautions were taken from the moment that forcible feeding was decided upon and, as stated above, Senior Medical officer saw the patient at this time and twice again in the course of the day» ${ }^{72}$. However, the report of the Chief Commissioner about his death was later debated in Council of State ${ }^{73}$.

31 Although, the Government of India received information about the death of Mahabir Singh on $18^{\text {th }}$ May 1933 it did not issue a press communiqué but news leaked out. Another hunger striker Vidhu Bhusan Sen was hospitalised for injury in his lungs. He had started bleeding through his nostrils ${ }^{74}$. Mankrishna Nama Das, a Bengali political prisoner, died of pneumonia on the morning of $26^{\text {th }}$ May. He began participating in the hunger strike on the $16^{\text {th }}$ May, and on $17^{\text {th }}$ it was decided to feed him artificially. On the $19^{\text {th }}$ instant he was admitted to hospital with lobar pneumonia. Throughout his illness he gave no trouble whatever, and the Senior Medical officer assured the Chief Commissioner that his death was due to natural causes and was in no way accelerated by his abstinence from food for one day. The Chief Commissioner reported: «His case diary will be posted. There is now only one convict suffering from pneumonia... Number of hunger strikers is now 39. They are offering less resistance everyday to forcible feeding and the Senior Medical officer considers their condition, with one or 
two exceptions, to be quite satisfactory. Strike has had no effect whatever on the ordinary convicts in the jail $»^{75}$. According to the Senior Medical Officer, "pneumonia started in consequence of reduced power of resistance to illness caused by hungerstrike and its progress was in no way accelerated by forcible feeding» ${ }^{76}$. The report of the Medical Officer on Mankrishna Nama Das was contradicted by Vinayak Vithal Kalikar, in the Council of State: «He started hunger strike on the $16^{\text {th }}$; food was administered to him through the mouth without resistance on the $17^{\text {th }}$ and on the $19^{\text {th }}$ he was admitted to the hospital with double pneumonia. This is the statement issued. It is stated that he took whatever was given to him, he gave no trouble and ultimately he died on the $26^{\text {th }} \ldots$ there is some link which we do not find in the communique and which can not explain away the circumstances» ${ }^{77}$.

After the death of two hunger strikers the Government of India considered it necessary to issue a press communique on $28^{\text {th }}$ May in which it repeated that Mahabir Singh had not died «as a result of the operation of feeding (...). The patient's resistance in his weakened state caused a severe shock to his system and led to his collapse and death». On the death of Mankrishna Nam Das the press communiqué stated: «His death was due to natural causes and was in no way accelerated by his abstinence from food for one day ${ }^{78}$. It accepted that the number of hunger strikers climbed up to 39 by $28^{\text {th }}$ May. Another political prisoner Mohit Mohan Maitra convicted in connection with the terrorist movement in Bengal joined the hunger strike on $12^{\text {th }}$ May and died of double lobar pneumonia on the $28^{\text {th }}$ May. It was again said that his vitality was impaired by the hunger strike ${ }^{79}$.

The news about the death on a third prisoner had travelled even before the press communiqué issued by the Government of India. The citizens of Calcutta organised a protest meeting in the Albert Hall on $30^{\text {th }}$ May, presided over by Santosh Kumar Bose, the City Mayor. The first Resolution read: «This meeting of the citizens of Calcutta has learnt with great concern and sorrow the news of the continued hunger-strike of the 39 political prisoners in the Cellular Jail at the Andamans and of the death of Sjts. Mahabir Singh of Lahore, Mankrishna Namdas of Mymensingh and Mohit Mohan Maitra of Calcutta and demands an immediate and open enquiry into the circumstances leading to the deaths and hunger-strike». Another Resolution strongly protested against the reopening of Andaman cellular jail for the deportation of political prisoners ${ }^{80}$.

The number of hunger strikers reached 45 on $5^{\text {th }}$ June with one exception their condition was reported to be satisfactory and a fair number of them were taking the feeding tube voluntarily. In view of the uncertainty of the length of strike and of number of convicts who might eventually join it the Chief Commissioner demanded one extra Assistant Surgeon ${ }^{81}$. The Government of India asked Lieutenant Colonel Barker, O.B.E., I.M.S., Inspector General of Prisons, Punjab, who had special experience of hunger strikes, to proceed to the Andamans for consultations about medical arrangements ${ }^{82}$.

On $13^{\text {th }}$ June 1933 Azhar Ali, Amar Nath Dutt, B.V. Jadhav, S.C. Jog, B.N. Misra, S.C. Mitra, Gaya Prasad Singh and K.B. Thampan, members of the Legislative Assembly met Sir Harry Haig, the Home Member to discuss the situation arising out of the hungerstrike. Mr. Jadhav regretted that Government had not thought fit to publish the names of the prisoners on hunger strikes, saying it would have relieved the anxiety of relatives. He also raised questions about the effect of the climate in the Andamans upon the vitality of the prisoners and about defective medical arrangements. Finally, he 
stated «that the Cellular Jail had been closed and the transfer to it of these prisoners had arose suspicion in regard to the motive of government which would best be allayed by the publication of periodic statements and the holding of an impartial enquiry» ${ }^{83}$. Mr Mitra stated, «that he had been advised by doctors that pneumonia might result from food being given unskilfully». Mr Jog and Mr Thampan asked «for an attempt to be made to meet their grievances» ${ }^{84}$. Sir Harry Haig emphatically refuted all the charges and made it clear that the colonial government was not ready to comply with the demands of the hunger strikers. Instead, he informed them that Government was planning to send Lieutenant-Colonel Barker, one of its officers from Punjab well experienced in dealing with such strikers ${ }^{85}$.

The Government of India was reluctant to publish the names of the political prisoners who were on hunger strike, but the policy proved to be self-defeating. It raised the anxiety of all the families of political prisoners transferred to cellular jail. The rising temper of the public opinion attracted the attention of newspapers, political parties and prominent citizens. The Free Press Journal of June $16^{\text {th }}$ claimed that Niranjan Sen Gupta, Satish Prakashi, Sudhanshu Das Gupta, Nishi Kant Chowdhury, Narayan Roy, Bhupal Bose, Batukeshwal (sic-Batukeshwar) Datta and Sushil Das Gupta were on hunger strike. Mr. Vinayak Vithal Kalikar later mentioned these names in the Council of State, and was not contradicted by Government ${ }^{86}$. In fact, all the prisoners mentioned by Free Press Journal were on hunger strike ${ }^{87}$.

Lieutenant-Colonel Barker arrived at Port Blair on the afternoon of June $14^{\text {th }} 1933^{88}$. Barker found $« 58$ terrorist prisoners on hunger strike in addition to 20 other terrorists who refused to work but continued to take food $\|^{89}$. Of the 55 on hunger strike, 35 were those who had been sent to Port Blair as B class prisoners, the rest were $\mathrm{C}$ class. The total number of prisoners in the cellular jail was 112. Barker found that ten days before his arrival «there had been a small outbreak of Influenza among them, and three were still suffering. They were located separately at the top of one of the wings of the Jail, in rooms made by the conversion of two cells into one room. Those strikers who had no intercurrent disease were located in small groups in other rows of cells; while nonstriking terrorists continued to be treated in that part of the main hospital which had been set apart for them».

After Barker's arrival the 55 hunger-strikers were attended to by the S.M.O., Cap. Edge, the new Assistant Surgn., Dr. Todd, four Sub.Asst. Surgeons, one compounder, a squad of ordinary prisoners, one of whom assisted in the preparation of the food, and the others detailed in groups of three and four to each Sub-Assistant Surgeon to hold the head and limbs, of any prisoner who resisted artificial feeding.

Barker found that the rice supplied to $\mathrm{C}$ class prisoners was deficient in anti-Beri-Beri constituents and that vegetables supplied were not up to the standard of most Indian jails. He suggested the growing of more vegetables in the Hospital garden, and the use of varieties of dhals (pulses) in place of only one kind of dhal. For night urinals in the cells, he recommended a receptacle with a flat base and a wider top. He held that existing latrines were good enough for $\mathrm{C}$ class prisoners but those for $\mathrm{B}$ class could be improved by providing each seat with its own door in front for greater privacy. Barker concluded his report by mentioning that not a single complaint was made to him by any of the 55 hunger strikers against the conduct of those in charge of them.

40 Lt. Col. Barker was known for his expertise in conducting forced feeding at Lahore Central Jail. The hunger strikers were fed not less than three times a day. The prisoners 
in hospital were fed at the interval of four hours. Barker reported that this system engaged members of the staff at work practically all day long. In his opinion such frequent feeding was both unnecessary and «contra-indicated», as every passage of a tube added to the possibility of causing irritation of the nasal passages or «the mechanical carrying down of germs to an abraded surface of the air passage». On the other hand, if the patient struggled, there was also the possibility of exhaustion if this happened three or four times a day. Barker's Lahore experience had taught him that by increasing the size and nutritive value of each feed it was quite possible to keep the strikers in health with two, or even one, feed a day. The number of feeds was reduced to a maximum of two per day and the volume of each feed was increased to one seer equivalent to roughly $2 \mathrm{lb}$.

41 In fact, Barker had also reduced the number of feeds as a tactic to force the prisoners to abandon the hunger strike. He reported: «As the resistance put up by the strikers was, in most cases, purely nominal, it was evident that the small and temporary discomfort of the passage of a tube was no inducement to the prisoners to give up their strike». He therefore decided not only to reduce the number of feeds a day but in selected cases, to omit the feed for a resisting prisoner on any one morning or evening. In other cases, prisoners were informed that they would not be artificially fed that day and their food was merely placed in their cells. A third batch had all water removed from their cells and it was replaced by milk. Thirst, Barker wrote, «always causes a more urgent desire than hunger».

Barker claimed that the results were not long in the showing. In the first night, the hunger strikers, whose water had been replaced by milk, threw it out into the yard. «The second night they left it untouched in their cells. On the next morning $\left(20^{\text {th }}\right.$.) they all complained of weakness and of being 'not so well', and there was a general desire on the part of every hunger striker to end the strike if it could be done with proper formality and without too obvious a surrender. Those whose artificial feed had been omitted owing to their threat of vigorous resistance took care next day not to resist for fear of losing their rations». Yet until June $22^{\text {nd }}$ none of the hunger strikers had given in. Therefore, water was issued to those who had been supplied with milk only. However, the condition of all the hunger strikers, including those suffering with influenza, was satisfactory.

«Artificial feeding», Barker proposed as a future course of action, «should be resorted to (even if the patient is conscious) if the Medical officer considers that it is the only means whereby the prisoner can be kept alive. He declared «In the treatment of the hunger-strikers at Port Blair, artificial feeding was, I think, started before it was absolutely necessary to save life. To put the case in another way, several of these prisoners could, in my opinion, have continued to abstain from food for a further 3-4 days and yet have recovered without artificial feeding had they, at the end of this period, consented to take food by the normal method». Barker suggested the immediate isolation of strikers from other prisoners to prevent the spread of such tacties. In certain cases he recommended rectal feeding before nasal feeding. In case of nasal feeding he recommended prior examination of the mouth, nose and throat and treatment if any infection was detected, and regular treatment of the air passages by gargles, inhalations and, sprays. If there was any inflammation of the throat or lungs artificial feeding immediately should be stopped. In his opinion it was better to risk death by inanition rather than add to the risk of death by diseases of the lungs. He also 
said the number of artificial feeds should be reduced to the minimum required to keep the prisoner alive.

\section{The power of spirit and official face saving} expertise was not showing any promising result. The spirit of resistance in the cellular jail was not scaling down. Public agitation on the mainland was mounting and the government was finding it difficult to justify its stand. The jail authorities were not in a position to afford a single more casualty, especially in the presence of Lt.Colonel Barker. Therefore, the jail authorities resorted to a honourable compromise and the hunger strike was called off in the evening of $26^{\text {th }}$ June ${ }^{90}$. Later, Sir Harry Haig, the Home Member asserted in the Council of State that the hunger strike was abandoned unconditionally ${ }^{91}$. However, Dhirendra Nath Choudhury gives a different account: "Chief Commissioner sent Jail Superintendent to negotiate with us. The Jail Superintendent told us that Chief Commissioner would fulfil all our demands. He will give us privileges we never had dreamt. We told him that no individual could take a decision. Therefore, collect us at one place. Thereafter we were brought on stretchers at one place with a warning to take a decision immediately. We decided to terminate the hunger strike from that very day» ${ }^{92}$. Sinha's version also confirms that the hunger strike was not abandoned unconditionally ${ }^{93}$.

assessment also emerges from an evaluation of government's actions taken within a few months. Many of the grievances of the hunger strikers were redressed in January 1934 when the Chief Commissioner, Andaman and Nicobar Islands, framed rules, under section 60 of the Prisons Act 1894, to regulate the classification and treatment of convicted prisoners ${ }^{94}$. In the Council of State Mr. Kalikar, a member, made this point: «My submission is that if their grievances were genuine-and it seems that some of their grievances were genuine because some of the grievances were redressed afterwards by the Government -Government could have taken their grievances into account from the beginning and avoided this difficult hunger strike which caused the death of these three unfortunate prisoners. The grievances of these political prisoners were about proper diet, supply of light, newspapers like Statesman, proper and timely medical aid and correspondence with their relatives and Government. Some of the grievances have been remedied and I therefore submit that Government committed a blunder in not paying attention to the grievances of these political prisoners in the beginning so that this catastrophe could have been easily avoided» ${ }^{95}$.

The framing of the new set of rules overhauled the existing conditions of political prisoners in the cellular jail. It was a great victory for the hunger strikers. In 1998, Bankim Chakravarty, Dhirendra Nath Choudhury, Provot Chakravarty and Ram Chandra Das all participants in the hunger strike recalled the changed atmosphere of cellular jail after the abandonment of the hunger strike ${ }^{96}$. The concessions included the establishment of a library, permission to play football, a common kitchen, political classes and even the circulation of handwritten pamphlets by the political convicts. Even the office of the Secretary of State for India later accepted that certain grievances of the hunger strikers were remedied after the hunger strike ended and that it was difficult to say "convincingly» that the hunger strike was "without justification» or might not have been avoided especially if they made representations before

Crime, Histoire \& Sociétés / Crime, History \& Societies, Vol. 7, n² | 2003 
threatening to strike. It was also admitted that the hunger strike was not «properly handled» by the authorities and that the jail superintendent who was 'nervous' of terrorist prisoners was not very good at dealing with them ${ }^{97}$.

The termination of the hunger strike did not bring any change in the transportation policy of the Government of India and the transportation of the convicts, including political convicts, continued to be in practice till June $1937^{98}$. But the cellular jail was no more a hell for political prisoners. A tremendous change also had taken place in the political atmosphere of India. The militant nationalist movement had receded to its lowest ebb, and in pursuance of the Government of India Act 1935 autonomy was granted to Indian provinces. In the provincial elections of January 1937 the Indian National Congress won clear majority in the six provinces. When the Congress Ministries were formed in March 1937 one of their first measures was the release of political prisoners in their respective provinces. This prompted political prisoners in the cellular jail to resort to another hunger strike to press for their release and for the abandonment of transportation of political prisoners. On July 24, 1937, 187 political prisoners of Cellular Jail undertook the fourth and last hunger strike while 72 struck work. This was an altogether different kind of hunger strike and did not meet with repressive measures from the jail authorities ${ }^{99}$. Later, Mahatma Gandhi intervened and an agreement between him and Viceroy Lord Linlithgow paved the way for the release of those terrorist prisoners ready to give an undertaking not to engage in violent activities for the future.

The terrorist prisoners at the penal settlement were ultimately transferred in phases to mainland prisons ${ }^{100}$. The last batch of 109 terrorist prisoners left Andamans on $18^{\text {th }}$ January $1938^{101}$. Even after the termination of the threat of political militancy convicts continued to be transported from mainland prisons on a voluntary basis to provide a labour force up to $1942^{102}$. Transportation was terminated, in practice, only during Second World War when Japanese forces captured the Andamans on $23^{\text {rd }}$ March 1942. The victory of the Allies leading to the surrender of Japan on $15^{\text {th }}$ August 1945 paved the way for the reoccupation of these Islands by the British forces in October 1945. In the meantime the Home Department of the Government of India had recommended the closure of the penal settlement ${ }^{103}$. Penal settlement was abolished and a free pardon was granted to all convicts. The colonial policy of maintaining a penal settlement at Andaman Islands terminated with the transfer of power from London to New Delhi.

\section{Conclusion}

Even from behind prison walls nationalist prisoners presented a well-determined political resistance to colonial administration through mass hunger strikes. This technique exposed the discriminatory treatment of political prisoners and fanned public opinion against the colonial regime. The colonial administration evaluated such hunger strikes as mere insubordination, which was to be discouraged by a refusal to make concessions. The timing to the 45-day hunger strike of May-June 1933 by around 55 militant prisoners coincided with the comparative lull in the arena of national struggle. After the conclusion of the second Round Table Conference in 1931, the government was busy formulating the Government of India Act. Gandhi's civil disobedience movement of 1930-1931 had been called off and all the political parties in India were waiting for the government to finalise a new constitution. The tide of 
militancy was also ebbing when the news of the hunger strike at the Andaman Islands revitalised the political atmosphere.

To meet the challenge of nationalist prisoners the jail administration adopted a number of measures including the isolation of each hunger striker and the coercive option of «forced feeding». The legal system sanctioned this on the principle of «safe custody", an obligation to protect the lives of prisoners in its custody. A tortuous method of «forced feeding» was devised by the jail administration. However, the death of three prisoners due to the negligence of jail authorities put government on the defensive. It had to satisfy agitated queries from the members of the Council and to provide a rational justification of its policies regarding transportation and treatment of political prisoners in the cellular jail. The decision to send Lt. Col. Barker from Punjab was in itself an acknowledgement of the failure of jail authorities to deal with the hunger strike. Despite Barker's tactics, which included a reduction of the number of feeds the hunger strike continued for a further twelve days. The jail authorities even failed to stop the leakage of news, the deaths which led to mass protests and demonstrations on the mainland. The hunger strike defeated the colonial policy of segregating «dangerous» ideas. Though government claimed that the hunger strike was abandoned unconditionally, in fact the colonial government had to amend the existing rules and redress the grievances of political prisoners. This hunger strike was the last milestone in the history of militant resistance to colonial rule which forced a stubborn colonial bureaucracy to yield and destroyed the dread image of «black waters» - the penal settlement at the Andaman Islands.

BIBLIOGRAPHY

\section{Books and memoirs}

Mathur, L. P., History of the Andaman Islands, 1756-1966, Delhi, Sterling Publication, 1968.

Mathur, L. P., Kala Pani: History of Andaman and Nicobar Islands with a Study of India's Freedom Struggle, Delhi, Eastern book corporation, 1985.

Majumdar, R. C., Penal Settlement in Andamans, New Delhi, Gazetteers unit, Department of Culture, Ministry of Education and Social Welfare, Publication Division, 1975.

Savarkar, V. D., The Story of my Transportation for Life (English translation by Professor V. N. Naik), Bombay, Sadbhakti Publications. 1950.

Sen, S., Disciplining Punishment: Colonialism and Convict Society in the Andaman Islands, Oxford, Oxford U.P., 2000.

Sinha, B. K., In Andamans: The Indian Bastille, Prafulla C. Mitra, 24/30, The Mall, Cawnpore, 1939.

Singh, U. K., Political Prisoners in India, Oxford, Oxford U.P., 1998. 
Tendulkar, D. G., Mahatma: Life of Mohandas Karamchand Gandhi, vol. 1, 1869-1920, New Delhi, Publication Division, Government of India, 1951.

Verma, S., Sansmritiyan (The memoirs), Lucknow, Martyrs Memorial and Freedom Struggle Research Center 1991.

\section{India office records and library London}

L/P\&J Series- Collection 115, 115/1A and 115/1AA (Jails and Reformatories, Andaman and Nicobar Islands: Use as penal settlement and reports of Chief Commissioner).

Jnanananda, S., Hunger strike and death of the political prisoners in the Andamans, A booklet sent from S. C. Mitra, President, Andaman Prisoner's relief League, 37, Serpentine Lane, Calcutta, $11^{\text {th }}$ June 1933 to Sir Samuel Hoare, Secretary of State for India, London.

\section{Unpublished project reports}

Srivastava, P. K., Oral history of freedom struggle with special reference to ex-Andaman freedom fighters, 1921-1947, an unpublished report submitted to the Indian Council of Historical Research (New Delhi) and Martyrs Memorial and Freedom Struggle Research Center (Lucknow), 1992.

Srivastava, P. K., Oral history of freedom struggle with special reference to ex-Andaman, naval mutiny and freedom fighters of 1942 movement, unpublished report submitted to Indian Council of Historical Research (New Delhi) and Martyrs Memorial and Freedom Struggle Research Center (Lucknow), 1998.

\section{NOTES}

1. The couplet of Pushkin was found scribbled on the first page of the notebook of Mahabir Singh the first casualty of the hunger strike of 1933 in the cellular jail (Verma, 1991, p. 139).

2. Singh (1998, p. 49).

3. Verma (1991, p. 7).

4. Tendulkar (1951, p. 150).

5. Singh (1998, p. 51).

6. Sen $(2000$, p. 6$)$.

7. Sen (2000, p. 18).

8. IOR: Vinayak Vithal Kalikar, Council of State Debates, $11^{\text {th }}$ September 1933, p. 246, P\&J 3932/1933.

9. IOR: Terrorist Prisoners in the Andamans, Council of State, $11^{\text {th }}$ September 1933, p. 251, P\&J 3932/1933.

10. Majumdar (1975, p. 148).

11. Singh (1998, p. 51).

12. Singh (1998, pp. 51-52 fn.).

13. Majumdar (1975, p. 201).

14. Sen (2000, p. 265).

15. IOR: Terrorist Prisoners in the Andamans, Council of State, $11^{\text {th }}$ September 1933, p. 251, P\&J 3932/1933.

16. IOR: Minute Paper, P\&J 5339/1932. 
17. IOR: Extract from Chapter XVII of Interim Report of the General Purposes Sub - Committee of the Retrenchment Advisory Committee, December 1931, Part II, Andaman and Nicobar Islands.

18. Majumdar (1975, p. 281).

19. IOR: Jail policy in the Andaman, Summary for Council, From Home Department, Government of India, D. O. No. 111/44-Jails, $21^{\text {st }}$ August 1945, To J.P. Gibson, Secretary, Political Department, India Office, P\&J 8496/1945.

20. IOR: Report of the discussion between the Government of India and the Governor of Bengal, P\&J 2824.

21. IOR: Minute Paper, 7.6.32, Public and Judicial Department, P\&J 5339/1932.

22. Ibid.

23. Ibid.

24. IOR: Minute Paper, P\&J 5339/1932.

25. IOR: Telegram 2544, Home Department, dated 15 ${ }^{\text {th }}$ November 1932, P\&J 5588 of 1932.

26. IOR: Legislative Assembly Debates, 14 November 1932, pp. 1975-1976.

27. IOR: See Express letters from Joint Secretary to the Government of India Simla/New Delhi to Secretary of State for India, P\&J 1932 to 1937.

28. IOR: Council of State Debates, $4^{\text {th }}$ March 1933, p. 123, P\&J 1184/1933.

29. IOR: From Home Department Government of India, Simla, the $25^{\text {th }}$ May 1933, No. 19/F. 11/1/33-jails to His Majesty's Under Secretary of State for India, Public and Judicial department, India Office, London, P\&J 2239/1933.

30. Ibid.

31. IOR: Extract from the Report on the Administration of the Police in Bihar and Orissa for the year 1930, Enclosure, Home Department, Government of India, and D.O.No. D. 9061/32-Poll, the $28^{\text {th }}$ November 1932,P\&J 5876/1932.

32. Ibid.

33. Ibid.

34. IOR: To Secretary of State, telegram $3^{\text {rd }}$ November 1932, No. 2457, P\&J 5339/32.

35. IOR: Telegram from the Secretary of State to the Government of India, $12^{\text {th }}$ November 1932 , No. 2943, P\&J 5339/32.

36. Ibid.

37. IOR: List of political prisoners whose removal to the Cellular Jail at Port Blair, between August 1932 and April 1933, was ordered by the Governor-General in Council under section 29(1) of the Prisoners Act (III of 1900) as amended by Act I of 1903, from Home Department Government of India, Simla, the $25^{\text {th }}$ May 1933, No. 19/F.11/1/33-Jails to His Majesty's Under Secretary of State for India, Public and Judicial department, India Office, London, P\&J 2239/1933.

38. Ibid. Three political prisoners -Ramendra Narayan Biswas and Madan Mohan Roy Choudhury from Bengal and Ishwar Dayal Singh from Bihar and Orissa- were not deported by then. The two other prisoners -Birendra Nath Roy and Mukul Ranjan Sen Gupta from Bengal- were returned to Central Jail, Alipore Calcutta, on account of their ill health (IOR: Jnanananda, p. 2).

39. IOR: Minute Paper, P\&J 5339/1932.

40. IOR: Jnanananda (1931, p. 1) (published also in the «Amrit Bazar Patrika», «Advance», «Liberty», «Anand Bazar Patrika», «Bangabani» of Calcutta, «Bombay Chronicle», «Free Press Journal» of Bombay, «Hindu» of Madras etc.).

41. Srivastava (1992, Appendix VII).

42. IOR: Report On the Medical Aspects of the Hunger strike in the Cellular Jail, Port Blair, From Lieut. -F.A.Barker, O.B.E., I.M.S., Inspector-General of Prisons, Punjab to the Secretary to The Government of India, Home Department, Simla, June $22^{\text {nd }} 1933$, From Home Department, Government of India, No. 26/F.70/4B/32-Jails to His Majesty's Under Secretary of State for India, India Office, London, the $27^{\text {th }}$ July 1933, P\&J 3026/1933.

43. Ibid. 
44. Srivastava (1992, Appendix VII).

45. Sinha (1939, pp. 32-39).

46. IOR: list of political prisoners whose removal to the Cellular Jail at Port Blair, between August 1932 and April 1933, was ordered by the Governor-General in Council under section 29(1) of the Prisoners Act (III of 1900) as amended by Act I of 1903, from Home Department Government of India, Simla, the $25^{\text {th }}$ May 1933, No. 19/F.11/1/33-Jails to His Majesty's Under Secretary of State for India, Public and Judicial department, India Office, London, P\&J 2239/1933].

47. Srivastava (1998, p. 48).

48. Srivastava (1992, Appendix VI).

49. Srivastava (1998, p. 38).

50. Srivastava (1998, p. 47).

51. IOR: From Home Department, Government of India to Secretary of State for India, dated Simla, $7^{\text {th }}$ June 1933 No. 1417 , repeating telegram from Andamans, June $5^{\text {th }}$ for information, P\&J 2210/1933.

52. The Government of India informed the Secretary of State: « 29 political convicts in C class, transported after August 1932» to the Cellular Jail of the Andaman Islands, «at the instigation of K.B. Dutt» (sic- B.K. Dutta), Lahore conspiracy convict, commenced a hunger-strike on May 12, 1933 «as a protest that their grievances were not being redressed». IOR: From Home Department, Government of India to Secretary of State for India, dated Simla, 21 ${ }^{\text {st }}$ May, 1933 No 1273 , repeating telegram from Andamans, $18^{\text {st }}$ May for information, P\&J 1941/1933.

53. Sinha (1939, pp. 39-40).

54. IOR: From Home Department, Government of India to Secretary of State for India, dated Simla, $7^{\text {th }}$ June 1933 No. 1417 , repeating telegram from Andamans, June $5^{\text {th }}$ for information, P\&J $2210 / 1933$.

55. Ibid.

56. IOR: Jnanananda (1933, pp. 10-11).

57. Article 1052 of the Jail Code, Ibid. p. 11.

58. Chapter XXXIV, Rule 24, Ibid. p. 11.

59. Chapter XXXIV, Rule 24, Ibid. p. 11. p. 12.

60. Chapter X, Rule 553, Ibid. p. 12. «All money or other articles in respect whereof no order of a competent court has been made and which may with proper authority be brought into the prison for his use shall be placed in the custody of the Jailor... any property or money belonging to a prisoner may at any time during his imprisonment be delivered to his friends with the approval of the superintendent under an authority signed by the prisoner».

61. Chapter XVII A- Rule 689 B, Ibid.p. 12.

62. Rule 689 A, Ibid. p. 13.

63. Chapter XXXIV- Rule 22 (1), Ibid. p. 13.

64. The amendment was made by the Lt. Governor in Council under the power conferred on him by section 60 of the Prisons Act, 1894, by the insertion of Rule 100-A in the Bengal Jail Code whereby force feeding was made legal. Singh (1998, p. 49 f. n.).

65. IOR: From O'Donnell, Secretary to the Government of India to J.E.Ferard, Secretary, Judicial and Public Department, India Office, Delhi, the $16^{\text {th }}$ November 1922, No. F. 201/XX, Government of India, Home Department (Political).

66. Ibid. p. 2.

67. IOR: From O'Donnell, Secretary to the Government of India to J.E.Ferard, Secretary, Judicial and Public Department, India Office, Delhi, the $16^{\text {th }}$ November 1922, No. F. 201/XX, Government of India, Home Department (Political). pp. 3-4.

68. IOR: Report On the Medical Aspects of the Hunger strike In the Cellular Jail, Port Blair, From Lieut. -F.A.Barker, O.B.E., I.M.S., Inspector-General of Prisons, Punjab to the Secretary to The Government of India, Home Department, Simla, June $22^{\text {nd }} 1933$, From Home Department, 
Government of India, No. 26/F.70/4B/32-Jails to His Majesty's Under Secretary of State for India, India Office, London, the $27^{\text {th }}$ July 1933, P\&J 3026/1933.

69. Srivastava (1992, Appendix 6).

70. IOR: From Government of India, Home Department to Secretary of State for India, repeating telegram of $18^{\text {th }}$ May from Chief Commissioner, Andaman and Nicobar islands, $21^{\text {st }}$ May 1933 , No. 1273, P\&J 1941 of 1933.

71. IOR: From Home Department, Government of India to the Secretary of State for India, repeating telegram of May $20^{\text {th }}$ from Chief Commissioner, Andaman and Nicobar Islands, No. $1325,28^{\text {th }}$ May 1933, P\&J 2064/1933.

72. Ibid.

73. IOR: Vinayak Vithal Kalikar, Council of State, $11^{\text {th }}$ September 1933, P\&J 3932/1933.

74. Srivastava (1998, p. 38).

75. IOR: From Government of India, Home Department to Secretary of State for India, repeating telegram of $26^{\text {th }}$ May from Chief Commissioner, Andaman and Nicobar islands, $28^{\text {th }}$ May 1933 , No. 1325, P\&J 2064 of 1933.

76. IOR: From Home Department, Government of India to Secretary of State for India, dated Simla, $7^{\text {th }}$ June 1933 No. 1417 , repeating telegram from Andamans, June $5^{\text {th }}$ for information, P\&J 2210/1933.

77. IOR: Vinayak Vithal Kalikar, Council of State, $11^{\text {th }}$ September 1933, P\&J 3932/1933.

78. IOR: Press Communiqué issued by Home Department, Simla, the $31^{\text {st }}$ May 1933, Enclosure No. 1, From Home Department, Government of India, No. 21/F.70/4-B/32-Jails, to His Majesty's Under Secretary of State for India, London, Simla, the $19^{\text {th }}$ June 1933, P\&J 2445/1933.

79. IOR: Press Communiqué issued by Home Department, Simla, the $31^{\text {st }}$ May 1933, Enclosure No. 2, From Home Department, Government of India, No. 21/F.70/4-B/32-Lails, to His Majesty's Under Secretary of State for India, London, Simla, the $19^{\text {th }}$ June 1933, P\&J 2445/1933.

80. IOR: Jnanananda (1933, p. 14).

81. IOR: From Home Department, Government of India to Secretary of State for India, dated Simla, $7^{\text {th }}$ June 1933 No. 1417 , repeating telegram from Andamans, June $5^{\text {th }}$ for information, P\&J 2210/1933.

82. IOR: Press Communiqué issued by Home Department, Simla, the $7^{\text {th }}$ June, 1933, Enclosure No. 3, From Home Department, Government of India, No. 21/F.70/4-B/32-Lails, to His Majesty's Under Secretary of State for India, London, Simla, the $19^{\text {th }}$ June 1933, P\&J 2445/1933. Lieutenant Colonel Barker sailed from Madras on June 11.

83. IOR: Press Communiqué issued by Home Department, Simla, the 13.6.1933, pp. 1-2, From Home Department, Government of India, No. 21/F.70/4-B/32-Lails, to His Majesty's Under Secretary of State for India, London, Simla, the $19^{\text {th }}$ June 1933 , P\&J 2445/1933.

84. Ibid.

85. IOR: Press communiqué issued by Home Department, Simla, 13.6.33, pp. 2-5, From Home Department, Government of India, No. 21/F.70/4-B/32- Jails, To His Majesty's Under Secretary of State for India, London, Simla, the $19^{\text {th }}$ June 1933, P\&J 2445/1933.

86. IOR: Vinayak Vithal Kalikar, Council of State, $11^{\text {th }}$ September 1933, P\&J3932/1933.

87. IOR: list of political prisoners whose removal to the Cellular Jail at Port Blair, between August 1932 and April 1933, was ordered by the Governor-General in Council under section 29(1) of the Prisoners Act (III of 1900) as amended by Act I of 1903, from Home Department Government of India, Simla, the $25^{\text {th }}$ May 1933, No. 19/F.11/1/33-Jails to His Majesty's Under Secretary of State for India, Public and Judicial department, India Office, London, P\&J 2239/1933].

88. IOR: Report On the Medical Aspects of the Hunger strike In the Cellular Jail, Port Blair, From Lieut. -F.A.Barker, O.B.E., I.M.S., Inspector-General of Prisons, Punjab to the Secretary to The Government of India, Home Department, Simla, June $22^{\text {nd }} 1933$, From Home Department, Government of India, No. 26/F.70/4B/32-Jails to His Majesty's Under Secretary of State for India, 
India Office, London, the $27^{\text {th }}$ July 1933, P\&J 3026/1933. All subsequent quotations pertaining to Barker's report are taken from this source.

89. In fact, when Lt.Col.Barker arrived he found 55 prisoners on hunger-strike but in his report he included also the three who had died.

90. IOR: Communiqué, dated Simla, the $27^{\text {th }}$ June 1933, P\&J 3932 of 1933.

91. IOR: Sir Harry Haig, Council of State, $11^{\text {th }}$ September 1933, P\&J 3932/1933.

92. Srivastava (1998, pp. 48-49).

93. Sinha (1939, p. 42).

94. IOR: See Rules framed by the Chief Commissioner, Andaman and Nicobar Islands, under section 60 of the Prisons Act 1894 to regulate the classification and treatment of convicted prisoners, $8^{\text {th }}$ January 1934, Statement laid on the Table, $16^{\text {th }}$ February 1934, Extract from Official Report of the Legislative Assembly Debates, p. 926.

95. IOR: Vinayak Vithal Kalikar, Council of State, $11^{\text {th }}$ September 1933, P\&J 3932/1933.

96. Srivastava (1998, pp. 35, 48-49, 69, 72.)

97. IOR: Minute Paper, Debate in Council of State, Hunger strike of Terrorist Prisoner, Andaman Cellular Jail, Received P\&J Dept 310ct 1933, P\&J 3932/1933).

98. IOR: Express letters from Joint Secretary to the Government of India Simla/New Delhi to Secretary of State for India, P\&J 1932 to 1937.

99. IOR: Draft note to the Cabinet, P\&J 3784/37.

100. IOR: From Joint Secretary to the Government of India to His Majesty's Under Secretary of State for India, Public and Judicial Department, dated New Delhi 14 January 1938, P\&J 359 of 1938, No. F. 5/1/38-Jails, GOI, Home Department).

101. IOR: Telegram from Home Department Government of India to the Secretary of State, No. F. 5/14/37-Jails dated $7^{\text {th }}$ January 1938.

102. IOR: Summary For Council: Jail policy in the Andamans, From Home Department, Government of India, D. O. No. 111/44- Jails, darted the $21^{\text {st }}$ August 1945, J.P. Gibson, Political Department, India Office, POL 8496/1945, pp. 1-2.)

103. Ibid.

\section{ABSTRACTS}

The rise of militancy in the beginning of twentieth century in India made the colonial authorities apprehensive of confining the nationalists on the mainland where they could spread their «dangerous ideas». The hunger strikes by the political convicts in the mainland prisons and in the cellular jail were an extension of the resistance movement against British colonialism. At the cost of three lives the hunger strike of 1933 kept the spirit of anti-colonial struggle alive during the lull created after Gandhi's Civil Disobedience Movement and exposed the mistreatment of political prisoners and the dehumanisation involved in forced feeding. The narratives of participants put together with government records unearths a minor resistance movement against a mighty colonial power.

La montée du militantisme en Inde au début du XX $\mathrm{XX}^{\mathrm{e}}$ siècle fit craindre aux autorités coloniales que si les nationalistes étaient internés sur le continent, ils pourraient propager leurs «idées dangereuses». Les grèves de la faim des détenus politiques dans les prisons continentales et dans la prison cellulaire étaient une extension du mouvement de résistance contre le colonialisme 
britannique. Au prix de trois vies, la grève de la faim de 1933 maintint l'esprit de la lutte anticoloniale durant la période de creux consécutive au mouvement de désobéissance civile de Gandhi. Elle mit en lumière les mauvais traitements infligés aux prisonniers politiques et la déshumanisation qu'impliquait le fait de les nourrir de force. Les récits des participants et les archives officielles permettent de mettre en lumière un micro-mouvement de résistance opposé à une puissance coloniale majeure.

\section{AUTHOR}

\section{PRAMOD KUMAR SRIVASTAVA}

Pramod Kumar Srivastava, Ph. D., D.Litt., is lecturer at the Department of Western History, Lucknow University, India. His publications include: Filipino Tribes and United States Penetration, The Eastern Anthropologist, July-Sept. 1984, 37, 3; Modern Asia: Culture and History, 2 volumes (in Hindi), Lucknow, India, 1984; Distortion and Contradiction, in Rajkishore (ed.) Politics of Hinduism (in Hindi), New Delhi, 1996. His current research is about political prisoners in the cellular jail, Andaman Islands, 1858-1948. 